Taken together with other research in food science, veterinary medicine and "a programme of commercial significance on the conversion of animal waste into protein in the form of worms", the government reckons that it is spending about $£ 2.4$ million a year on agricultural biotechnology and employing 110 of its own scientists and technicians as well as "a further 25 in universities".

Among the research councils with an
AlL is well with British biotechnology, and with the British government as well - that seems to be the principal message of the government's response to the critical report of the House of Commons Select Committee on Education, Science and the Arts, published last year. The committee complained that although British universities had made important contributions to the foundations of the industry, they were now so starved of funds that innovation had become encumbered and potential innovators persuaded to seek their fortunes elsewhere.

The government's response, published last week as a memorandum attached to a letter to Mr Christopher Price, MP, the committee's chairman, breaks new ground in the executive's dismissiveness of the legislature. The government says flatly that, contrary to the committee's opinion, the arrangements that it has made for public sector are "broadly right in scale and nature".

Acknowledging the committee's concern that the dual support system (twoway support of university research through the University Grants Committee and through the research councils) may be in danger of breaking down, the British government says that it is too soon to know how universities will respond to a recent plea that they should pay more attention to research, and that, in any case, the Secretary of State for Education and Science (Sir Keith Joseph) "shares this concern". The memorandum says that "a proportion" of the new posts to be created in British universities with uncovenanted funds will "be in disciplines which underpin biotechnology".

One of the select committee's chief recommendations was that the government should decide which government department was in charge of biotechnology. The answer, now provided, is that the Department of Industry will in future be responsible. To help the department decide how best to carry out its new responsibilities, "an Interdepartmental Committee on Biotechnology (ICBT)"' has been set up, with representation from other departments, research councils, the British

After listing the coordinating committees in biotechnology now extant in both the public and private sectors, the memorandum opines that "the existing committees adequately meet the various functions for which they were set up" but goes on to say that the "present spread of supporting biotechnology within the Technology Group and others.

committees is not considered to be excessive".

Enamoured of committees, subcommittees and the device of a "combination of subcommittees", the government rejects the advice from the House of Commons that there should be a separate agency of government with responsibility for biotechnology. Part of the government's difficulty seems to have been that its own agencies, the University Grants Committee included, responded to the request for a response to the House of Commons by listing the committees they had already, out of diligence, set up. The gibe that there are more British nationals deliberating on biotechnology than British biotechnologists may still be valid.

The British government's response to the House of Commons report goes on to list the steps that have been taken in recent years in the exploitation of biotechnology. Its memorandum says that the Agricultural Research Council, "recognizing the great potential for agriculture if it were possible to manipulate the genes of crop plants", has set up a programme involving 40 scientists at four of its laboratories and a further fifteen at "several universities" which is "in effect a national programme". To achieve coordination, the council also "convenes an annual discussion meeting".

\section{Migration of British biotechnologists}

THE loss of British biotechnologists to posts overseas is being tackled in a study commissioned by the Science and Engineering Research Council from the Institute of Manpower Studies. The objective is to estimate the future supply and demand of people with "key skills" and to recommend whether there should be a register to keep in touch with British biotechnologists working overseas.

Richard Pearson, director of the study, stresses that it is too early for any clear impression of the importance of the trend to have emerged. But the pattern of the emigration appears to be different from that in other fields such as microelectronics. Jobs in biotechnology are fewer and the skills required are more specific, so it is the top people (who are often "head-hunted") who leave to take them. Higher living standards and better research opportunities in the United States and elsewhere are usually sufficient reasons to persuade people to leave.

The 1981 cuts of university budgets kept down the number of research openings in the United Kingdom and probably, interest in biotechnology, the Medical Research Council emerges predominant. Something like $£ 17$ million of the council's spending in 1980-81 is reckoned to have been relevant, including $£ 1.7$ million for the development a monoclonal antibody for the purification of interferon. The government says that the research council's concern is "to try to hold a balance between maintaining a continued strength in basic research and exploiting opportunistically those discoveries with potential health care applications".

The Natural Environment Research Council, by contrast, is described in the memorandum as "relatively minor so far as biotechnology is concerned".

On one of the most contentious arguments of the House of Commons committee - that the arrangement between the Medical Research Council and the company Celltech Ltd should be looked into - the government has nothing to say except that the matter is being attended to. It emerges that the agreement is due to be reviewed during 1983, "two years before it expires", and that the exclusivity of the deal is on the agenda. Moreover, the government says, an earlier review of the arrangement would have been based on "inadequate experience". according to Pearson, account for some of the departures. But there is some evidence that recent government initiatives, and the successes of the partly public company Celltech, have persuaded some British expatriates with important skills to seek to return to Britain.

The lower standard of living in Britain remains a problem. Few British companies in the field offer their scientists equity holdings, and the salaries of scientists on civil service pay scales (a significant proportion of those the study will cover) have fallen markedly behind those of their administrative equivalents since 1978 .

A separate study initiated by CORDI, the EEC Committee on Research and Development, will look at the high level skill needed of the European semiconductor industry: in this area the exodus is predominantly from the industrial rather than the academic world. At the moment the recession is ensuring that demand in Britain remains at a low level, but, says Pearson, there is no room for complacency: an upturn in the economy could result in a shortage.

Tim Beardsley 